\title{
Flora of the cangas of Serra dos Carajás, Pará, Brazil: Plantaginaceae
}

\author{
André Vito Scatigna ${ }^{1,3}$ \& Nara Furtado de Oliveira Mota ${ }^{2}$
}

\begin{abstract}
This is a taxonomic study of the species of Plantaginaceae from the cangas of Serra dos Carajás, Pará, Brazil. We recorded five species, all members of the tribe Gratioleae: Bacopa monnierioides, B. myriophylloides, B. reflexa, Scoparia dulcis and Stemodia verticilata. All five species are widespread in Brazil, and B. myriophylloides is here cited for the first time for the State of Pará. We present detailed descriptions, illustrations, photographs and notes on morphology, distribution and phenology of these species.

Key words: Aquatic plants, FLONA Carajás, Gratioleae, Scrophulariaceae, taxonomy.

\section{Resumo}

Este é um estudo taxonômico das espécies de Plantaginaceae das cangas da Serra dos Carajás, Pará, Brasil. Registramos cinco espécies, todas membros da tribo Gratioleae: Bacopa monnierioides, B. myriophylloides, B. reflexa, Scoparia dulcis e Stemodia verticillata. Todas as espécies apresentam ampla distribuição no Brasil, sendo B. myriophylloides referida aqui pela primeira vez para o Estado do Pará. Apresentamos descrições detalhadas, ilustrações, fotografias e comentários sobre morfologia, distribuição geográfica e fenologia destas espécies.

Palavras-chave: Plantas aquáticas, FLONA Carajás, Gratioleae, Scrophulariaceae, taxonomia.
\end{abstract}

\section{Plantaginaceae}

Plantaginaceae Juss. has a worldwide distribution, with approximately 100 genera and 2,000 species, currently comprising several genera formerly placed within Scrophulariaceae sensu lato (Wettstein 1908; Albach et al. 2005). This Lamialean family is highly heterogeneous, including specialized aquatic herbs, chasmophytic subshrubs and even carnivorous species with unique morphology (Albach et al. 2005; Souza et al. 2009; Scatigna et al. 2015). In Brazil, 25 genera and ca. 140 species are currently recognized (BFG 2015). In Serra dos Carajás, we recorded three species of Bacopa Aubl., one species of Scoparia L. and one species of Stemodia L., all representatives of the Gratioleae, a mainly Neotropical tribe (Estes \& Small 2008).

\section{Key to the genera of Plantaginaceae in the cangas of Serra dos Carajás}

1. Aquatic or amphibious; calyx with unequal sepals or, if equal to sub-equal, then leaves pinnatifid .....

1'. Terrestrials; calyx with equal to sub-equal sepals and leaves entire

2. Corolla 4-lobed, rotaceous; calyx tetramerous; thecae not separated by the connective

2'. Corolla 5-lobed, bilabiate; calyx pentamerous; thecae separated by the connective

\footnotetext{
${ }^{1}$ Universidade Estadual de Campinas, Inst. Biologia, Prog. Pós-graduação em Biologia Vegetal, R. Monteiro Lobato 255, CP 6109, 13083-970, Campinas, SP, Brazil. ${ }^{2}$ Museu Paraense Emílio Goeldi, Coord. Botânica, Prog. Capacitação Institucional, Av. Perimetral, Terra Firme, 66077-830, Belém, PA, Brazil. nara.mota@gmail.com ${ }^{3}$ Autor para correspondência: andre_vs13@hotmail.com
} 


\section{Bacopa Aubl.}

Bacopa comprises aquatic or amphibian herbs with highly variable leaf morphology, blades entire, linear, elliptical, ovate or orbicular, or even pinnatifid; calyx pentamerous with free, usually unequal, rarely equal to sub-equal, sepals; corolla 5-lobed, bilabiate or slightly rotaceous; stamens 4 (rarely 2, 3 or 5) (Pennell 1946; Souza \& Giulietti 2009). The genus, with ca. 50 species is one of the largest within the tribe Gratioleae, with Tropical distribution, chiefly in the New World (Souza \& Giulietti 2009). In Brazil, 26 species are currently recognized (BFG 2015), three of which recorded in areas of canga of Serra dos Carajás.

\section{Key to the species of Bacopa in the cangas of Serra dos Carajás}

1. Leaves pinnatifid; sepals equal to sub-equal; ovary glandular-puberulent 1.3. Bacopa reflexa

1'. Leaves entire; sepals unequal; ovary glabrous.

2. Leaves opposite, narrowly ovate to lanceolate; flowers fasciculate, sessile or short-pedicelate; corolla tube externally glabrous 1.1. Bacopa monnierioides

2'. Leaves whorled, linear-lanceolate, falcate; flowers solitary, pedicelate; corolla tube externally glandular-pubescent 1.2. Bacopa myriophylloides

1.1. Bacopa monnierioides (Cham.) B.L.Rob. Proc. Amer. Acad. Arts 44(21): 614. 1909.

Figs. 1a-b; 2a-c.

Herbs, aquatic or amphibious, $3-30 \mathrm{~cm}$ long. Stems prostrate, ascendent or erect, simple or branched, usually terete, glabrous to densely glandular-puberulent towards the apex, rarely sparsely pubescent. Leaves opposite, glabrous, markedly glandular-punctate, sessile, narrowlyovate to lanceolate, apex acute, base truncate, sub-amplexicaul, margin entire, 2-20 × 1-5 mm. Flowers axillary, fasciculate, sessile or shortpedicellate, bi-bracteolate, emersed; pedicel ascending during anthesis, descending when fruiting, glandular-puberulent, glabrescent, to $3 \mathrm{~mm}$ long; bracteoles 2, opposite, glandularpunctate, linear-lanceolate, ca. $0.5 \mathrm{~mm}$ long. Sepals unequal, glandular-puberulent, outer ovate, apex acute, base rounded, 2-3 $\times 1-12 \mathrm{~mm}$, inner linear-lanceolate, apex acute, $2-3 \times 0.2-0.3 \mathrm{~mm}$, dimensions doubling when fruiting. Corolla lilacblue to blue; tube externally glabrous, $1-3 \mathrm{~mm}$ long; lobes orbicular-obovate, ca. $1 \mathrm{~mm}$ long. Stamens 4, reaching or slightly exserted above the throat. Ovary globose, ca. $0.75 \times 0.8 \mathrm{~mm}$, glabrous, style filiform, 1.2-2 mm long, stigma subglobose. Capsule ovoid ca. $2 \times 1.5 \mathrm{~mm}$.

Selected material: Canaã dos Carajás, Serra Sul, S11D, 6²4'14"S, 50¹8'37'W, 820 m, 18.V.2010, fl., M.O. Pivari et al. 1507 (BHCB); Serra da Bocaina, Lagoa do Buritiranal, 6 $6^{\circ} 18^{\prime} 45^{\prime}$ 'S, 49 $53^{\circ} 21^{\prime \prime} \mathrm{W}, 692$ m, 23.VI.2015, fl. and fr., N.F.O. Mota et al. 3412 (MG, UEC). Parauapebas, Serra Norte, N7, 609' 16"S, $50^{\circ} 10^{\prime} 18^{\prime \prime}$ 'W, $696 \mathrm{~m}, 26$.VI.2015, fl. and fr., N.F.O. Mota et al. 3432 (MG, UEC).
Bacopa monnierioides is highly variable regarding habit and leaf dimensions, this variability likely to be associated with water availability in the habitat. This species differs from the others in the entire leaves (vs. pinnatifid in B. reflexa), and opposite (vs. whorled in B. myriophylloides).

Bacopa monnierioides occurs from Panama to Argentina (Souza \& Giulietti 2009). In Brazil, it is widespread (BFG 2015). Serra dos Carajás: Serra Sul: S11D, Serra da Bocaina and Serra Norte: N7. Usually found in flooded areas. More abundant blooming is observed in temporary ponds during the dry season.

1.2. Bacopa myriophylloides (Benth.) Wettst. in Engler \& Prantl, Nat. Pflanzenfam. 4(3b): 77. 1891.

Figs. 1c-d; 2d-f.

Herbs, aquatic or amphibious, 10-20 cm long. Stems ascendent, simple or branched, usually terete, submersed part glabrous, emersed, villous, trichomes adpressed. Leaves 6-12 whorled, glabrous, submersed filiform, reddish, 4-22 $\times$ 0.1-2 mm long, emersed glandular punctate, linearlanceolate, falcate, apex acute, base connate, margin entire, $3-8 \times 0.2-0.3 \mathrm{~mm}$. Flowers axillary, solitary, emersed; pedicel ascending to erect during anthesis, sparsely pilous, ca. $8 \mathrm{~mm}$ long; bracteoles 1 or 2 , sometimes absent, linear-lanceolate, ca. $1 \mathrm{~mm}$ long. Sepals unequal, glandular-puberulent, ciliate, outer ovate, apex acute, base rounded, 2-3 × 1-2 mm, inner linear-lanceolate, apex acute, $2-3 \times 0.3-0.6$ $\mathrm{mm}$. Corolla lilac-blue; tube externally glandularpubescent, ca. $3 \mathrm{~mm}$ long; lobes oblong, ca. $1.5 \times 1$ $\mathrm{mm}$. Stamens 4, reaching the throat. Ovary ovoid, 


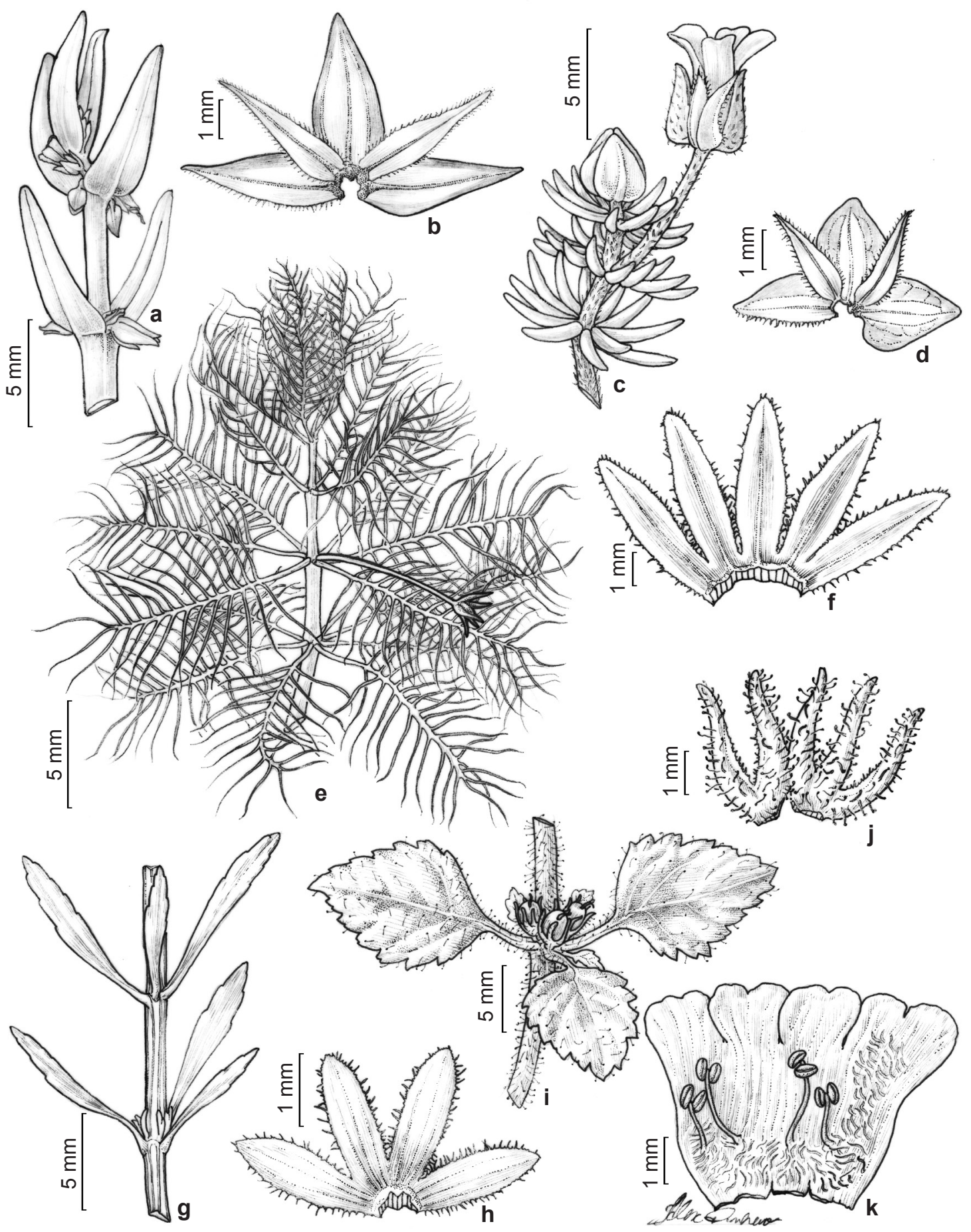

Figure 1 - a-b. Bacopa monnierioides - a. aerial branch showing leaves and flower insertion; b. open calyx with unequal sepals. c-d. Bacopa myriophylloides - c. aerial branch showing leaves and flower insertion; d. open calyx with unequal sepals. e-f. Bacopa reflexa - e. submerse branch showing leaves and flower insertion; f. open calyx with equal sepals. g-h. Scoparia dulcis - g. branch showing leaf arrangement; h. open calyx with equal sepals. i-k. Stemodia verticillata $-\mathrm{i}$. branch showing leaves and fruits; $\mathrm{j}$. open calyx with equal sepals; $\mathrm{k}$. open corolla showing anthers with separated thecae. (a-b. N.F.O. Mota 3432; c-d. N.F.O. Mota et al. 3407; e-f. N.F.O. Mota et al. 2989; g-h. A. Cardoso et al. 2002; i-k. N.F.O. Mota et al. 1164). Illustrations: Alex Pinheiro Araújo. 
ca. $0.7 \times 0.5 \mathrm{~mm}$, glabrous, surrounded by linear bristles, style filiform, ca. $2.2 \mathrm{~cm}$ long, stigma bi-globose. Fruit not observed.

Selected material: Canaã dos Carajás, Serra da Bocaina, Lagoa do Buritiranal, $6^{\circ} 18^{\prime} 43^{\prime \prime}$, 4952'21”'W, 692 m, 23.VI.2015, fl., N.F.O. Mota et al. 3407 (MG, UEC). Parauapebas [Marabá], Serra Norte, N1, 14.V.1982, fl., R. Secco et al. 191 (MG).

Bacopa myriophylloides is easily recognized by its linear-lanceolate aerial leaves, that are often falcate and 6-12 whorled (Figs. 1c; 2d-f). It also presents submersed, reddish, filiform, whorled leaves (Fig. 2d). Heterophylly is well documented in several aquatic plant species (Sculthorpe 1985; Cook 1990; Bell 2008), but is a rare feature among the Gratioleae, being found in the Old World aquatic genera Limnophila R.Br. and Hydrotriche Zucc. (Cook 1990), and referred by Pott \& Pott (2000) for South American B. myriophylloides. Whether the leaves of B. myriophylloides are actually whorled or opposite and palmatifid is still controversial, and developmental studies are needed to clarify this matter (Pennell 1946; Barroso 1952; Souza \& Giulietti 2009).

Bacopa myriophylloides is restricted to South America (Brazil, Venezuela, and Colombia) (Souza \& Giulietti 2009). In Brazil, the species are found in Amapá, Mato Grosso, Mato Grosso do Sul, Minas Gerais, Paraná, and Rondônia (BFG 2015); its occurrence in Pará is here recorded for the first time. Serra dos Carajás: Serra da Bocaina and Serra Norte: N1. Usually found in flooded areas. More abundant blooming is observed in temporary ponds during the dry season.

1.3. Bacopa reflexa (Benth.) Edwall, Bolm. Commiss. Geogr. Estado de São Paulo 13: 176. 1897. Benjaminia reflexa (Benth.) D'Arcy, Ann. Miss. Bot. Gard. 66: 194. 1979. Figs. 1e-f; 2g-i

Herbs, aquatic, submerged or amphibious, 10-35 cm long. Stems ascendent, simple or branched, terete, submersed glabrescent, emersed villous. Leaves (6-) 8 -whorled, glabrous, sometimes verrucose, pinnatifid, 4-26 $\mathrm{mm}$ long, segments filiform, 1-10 mm long. Flowers axillary, solitary, emersed; pedicel erect during anthesis, glabrous to sparsely glandularpuberulent, ca. 10-12 $\mathrm{mm}$ long during anthesis, up to $25 \mathrm{~mm}$ long when fruiting; bracteoles absent, linear-lanceolate, ca. $1 \mathrm{~mm}$ long. Sepals equal to sub-equal, glandular-puberulent, ciliate, apex acute, base truncate, $2.5-4 \times 0.8-1 \mathrm{~mm}$. Corolla lilac, with yellow patch on throat; tube externally glabrous, $2-3 \mathrm{~mm}$ long; upper lobes connate, erect, ca. $2 \times 1 \mathrm{~mm}$, lower lobe slightly keeled 3-6 mm long. Stamens 4, didynamous, inserted. Ovary ovoid, ca. $0.5 \times 0.3$ $\mathrm{mm}$, glandular-puberulent, surrounded by linear bristles, style filiform, ca. $1.5 \mathrm{~mm}$ long, stigma flattened. Capsule sub-globose, $2.5 \times 1.5 \mathrm{~mm}$.

Selected material: Canaã dos Carajás, Serra Sul, S11B, 621'22”'S, 50²3'26”'W, 703 m, 29.IV.2015, fl., N.F.O. Mota et al. 2972 (MG); S11D, 6²1'23”'S, $50^{\circ} 23^{\prime} 26^{\prime}$ 'W, 729 m, 2.XII.2015, fl., B.R.S. Silva et al. 3 (MG); Serra do Tarzan, 6 20 '2"S, 50 $0^{\circ} 9^{\prime} 45^{\prime \prime} \mathrm{W}$, 735 m, 27.III.2015, fl., P.L. Viana et al. 5687 (MG). Parauapebas [Marabá], Serra Norte, N3, 62'34”S, $50^{\circ} 12^{\prime} 33^{\prime}$ 'W, 698 m, 27.IV.2015, fl., N.F.O. Mota et al. 2954 (MG); N4, 66'8”S, 50¹1'14”'W, $718 \mathrm{~m}$, 26.III.2016, fl., R.M. Harley et al. 57494 (MG); N4WS, 66'36"S, 50¹1'11"W, 675 m, 23.IV.2012, fl., A.J. Arruda et al. 1058 (BHCB); N5, Trilha da Lagoa da Mata, 62'26”'S, 505'18”'W, 674 m, 30.IV.2015, fl., N.F.O. Mota et al. 2989 (MG).

Bacopa reflexa is easily differentiated from the other species of the genus by its pinnatifid leaves (Fig. 1e) and equal to sub-equal sepals (Figs. 1f; 2i). It is commonly confused with Cabomba Aubl., differing in the simply pinnatifid leaves ( $v s$. double-pinnatifid). The taxonomic position of Bacopa reflexa is still controversial, it has been treated as Benjaminia reflexa (Benth.) D'Arcy by some authors (D'Arcy 1979; Velasquez 1994; Burger \& Barringer 2000). It is hoped that molecular studies may help to resolve this issue (Souza \& Giulietti 2009).

Bacopa reflexa occurs from Central to northern South America (Souza \& Giulietti 2009). In Brazil, this species is found in Acre, Amapá, Amazonas, Goiás, Maranhão, Mato Grosso, Pará, and Roraima (BFG 2015). Serra dos Carajás: Serra Sul: S11B, S11D, Serra do Tarzan and Serra Norte: N3, N4, N4WS, N5. Usually found in flooded areas. Very abundant blooming is observed in temporary ponds during the dry season.

\section{Scoparia L.}

Scoparia comprises terrestrial herbs or subshrubs with linear, lanceolate, elliptical or pinnatifid leaves; calyx tetramerous or pentamerous, with free, equal sepals; corolla 4-lobed, rotaceous, with a tuft of trichomes at center; and 4 stamens with thecae not separated by the connective (Souza \& Giulietti 2009). The genus comprises from 10 to 20 species, depending on circumscriptions (Fries 1906; Barroso 1952; 

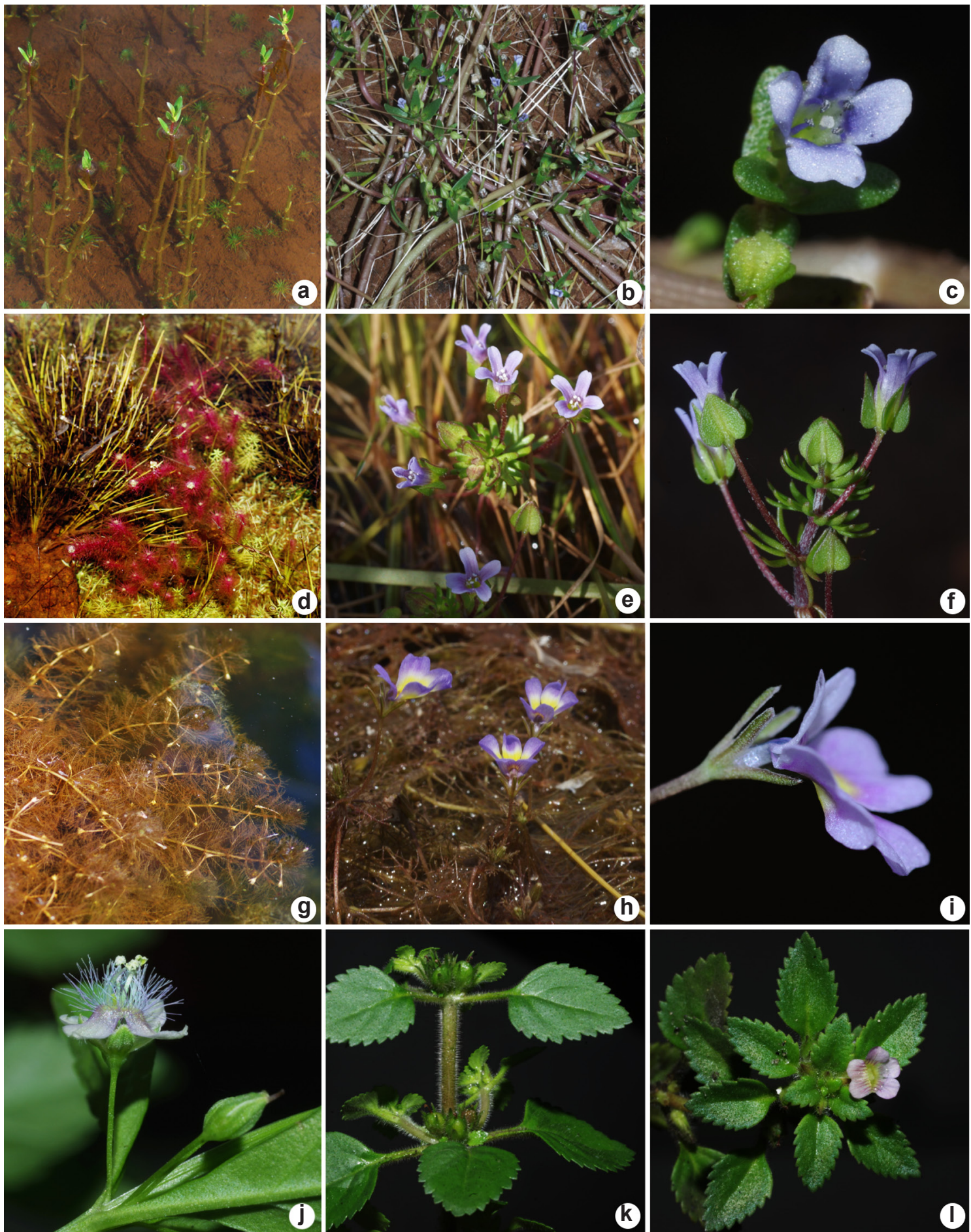

Figure 2 - a-c. Bacopa monnierioides - a. specimens in flooded habitat; b. flowering branches; $c$. frontal view of the flower. d-f. Bacopa myriophylloides - d. specimens in flooded habitat showing red submerse leaves; e. flowering branch in apical view; f. flowering branch in lateral view showing linear, curved leaves and unequal sepals. g-i. Bacopa reflexa - g. specimens in flooded habitat; h. flowering specimens; i. flower in lateral view. j. Scoparia dulcis - flower in lateral view showing tuft of trichomes. k-1. Stemodia verticillata $-\mathrm{k}$. fruiting branch with leaves in lateral view. 1. flowering branch in apical view. Photos: a -f, h. N.F.O. Mota; g, i. P.L. Viana 
Souza \& Giulietti 2009), occurring in southern Neotropics, especially in Argentina, Paraguay, Uruguay and southern Brazil, where six species are currently recognized (Souza \& Giulietti 2009; BFG 2015).

\subsection{Scoparia dulcis L. Sp. pl.: 116. 1753.}

Figs. 1g-h; $2 \mathrm{j}$

Herbs or subshrubs, terrestrial, $10-50 \mathrm{~cm}$ tall. Stems erect, usually branched, quadrangular, glabrous, sparsely glandular-punctate. Leaves opposite or 3-whorled, glabrous, markedly glandular-punctate, obscurely petiolate, obovate to narrowly elliptical, apex acute to rounded, base attenuated, margin entire, sub-entire to serrate, $3-13 \times 1-3 \mathrm{~mm}$. Flowers axillary; pedicel glandular-puberulent, 1-3 cm long; bracteoles absent. Calyx tetramerous; sepals ovate to obovate, apex roudend, margin ciliate, $3-4 \times 1-2$ $\mathrm{mm}$. Corolla white to pale lilac, with a tuft of pale lilac trichomes; lobes elliptic, 1-4×1-2 mm long. Stamens 4. Ovary ellipsoid, style filiform, usually persistent. Capsule globose, 2-4 × 1-3 mm.

Selected material: Canaã dos Carajás, S11D, 30.III.2015, fr., A. Cardoso et al. 2002 (MG). Parauapebas [Marabá], Serra Norte, N4, 17.III.1984, f1. and fr., A.S.L. Silva et al. 1862 (INPA, MG, NY).

Scoparia dulcis is characterized by the tetramerous calyx and rotaceous corolla with a tuft of trichomes at center (Fig. 2j).

Scoparia dulcis is one of the most widespread species of Plantaginaceae in the world, with pantropical distribution (Souza \& Giulietti 2009). In Brazil, it occurs in all states and in the Distrito Federal (BFG 2015). Serra dos Carajás: Serra Sul: S11D; Serra Norte: N4. Usually found in disturbed areas, such as N4 and S11D mine areas.

\section{Stemodia L.}

Stemodia presents wide morphological variation, from creeping annual herbs to perennial erect subshrubs; leaves sessile, with clasping base, or clearly petiolate; flowers sessile or pedicellate, with or without bracteoles; calyx pentamerous, with free, equal to subequal sepals; corolla 5-lobed, bilabiate; and stamens 4 , with two thecae separated by a connective in each anther. The genus, as currently delimited, comprises ca. 50 species distributed in the tropics, especially in the New World, usually occurring in open areas with moist soil (Turner \& Cowan 1993a, 1993b; Souza \& Giulietti 2009). In Brazil,
17 species are recognized (Scatigna et al. 2017), with a group of species concentrated in the wet lowlands of southern Brazil and another in the mountains of southeastern to northeastern Brazil, while some species have broader distribution (Souza \& Giulietti 2009).

3.1. Stemodia verticillata (Mill.) Hassl., Trab. Mus. Farmacol. 21: 110. $1909 . \quad$ Figs. 1i-k; 2k-1

Herbs, terrestrial, creeping, ca. $5 \mathrm{~cm}$ tall. Stems procumbent, usually branched, quadrangular, villous. Leaves 3-whorled, rarely opposite, sparsely villous, glandular punctate; petioles villous, $1-3 \mathrm{~mm}$ long; blades ovate, apex acute, base acute to obtuse, margin serrate to double-serrate, $3-13 \times 1-3 \mathrm{~mm}$. Flowers axillary, solitary, sessile or sub-sessile; pedicel villous, up to $2 \mathrm{~mm}$ long when fruiting; bracteoles absent. Sepals sub-equal, villous, lanceolate, apex acute, base acute, ca. $2.5 \times 0.6 \mathrm{~mm}$. Corolla lilac, throat yellow, tube internally yellow; tube externally glabrous, ca. $2.5 \mathrm{~mm}$ long; lobes orbicular, 0.5 $\mathrm{mm}$ diam. Stamens 4, didynamous, inserted, thecae separated by the connective. Capsule globose, ca. $2.5 \times 2 \mathrm{~mm}$.

Selected material: Parauapebas, Serra Norte, N1, $6^{\circ} 2^{\prime} 38^{\prime}$ 'S, 50 $16^{\prime} 56^{\prime} \mathrm{W}, 666 \mathrm{~m}, 12 . X I I .2007$, fl., N.F.O. Mota et al. 1164 (BHCB, ESA); N3, 6²'44”'s, 50¹3'09”'W, 692 m, 27.III.2012, fl., A.J. Arruda et al. 882 (BHCB).

Stemodia verticillata is characterized by sub-equal sepals and anthers with separated thecae (Fig. 1k).

Stemodia verticillata is the most widespread species of the genus, occuring in the Neotropics and West Africa (Souza \& Giulietti 2009). In Brazil, this species occurs in all states and in the Distrito Federal (BFG 2015). Serra dos Carajás: Serra Norte: N1, N3. Usually found in disturbed areas.

\section{Acknowledgements}

The first author thanks the Programa de Pósgraduação em Biologia Vegetal of UNICAMP for the Ph.D. scholarship. The second author thanks the Programa de Capacitação Institucional (MPEG/MCTI) for the grant. We thank Instituto Tecnológico Vale (01205.000250/2014-10) and CNPq (455505/2014-4) for financial support; Alex Pinheiro de Araújo for the line drawings; Dr. Pedro Lage Viana for photographs; and Dra. Maria do Carmo E. do Amaral for lending some of the reference books. 


\section{References}

Albach DC, Meudt HM \& Oxelman B (2005) Piecing together the "new" Plantaginaceae. American Journal of Botany 92: 297-315.

Barroso GM (1952) Scrophulariaceae indígenas e exóticas do Brasil. Rodriguésia 27: 9-64.

BFG - The Brazil Flora Group (2015) Growing knowledge: an overview of seed plant diversity in Brazil. Rodriguésia 66: 1085-1113.

Burger WC \& Barringer KA (2000) Family 193. Scrophulariaceae. In: Burger WC (ed.) Flora Costaricensis. Fieldiana, Botany, new series, 41: 1-69.

Cook CDK (1990) Aquatic plant book. SPB Academic Publishing, The Hauge. 228p.

D'Arcy WG (1979) Flora of Panama, part IX. Family 171. Scrophulariaceae. Annals of the Missouri Botanical Garden 66: 173-274.

Estes D \& Small RL (2008) Phylogenetic relationships of the monotypic genus Amphianthus (Plantaginaceae tribe Gratioleae) inferred from chloroplast DNA sequences. Systematic Botany 33: 176-182.

Fries RE (1906) Systematische Übersicht der Gattung Scoparia. Arkiv för Botanik 6: 1-31.

Pennell FW (1946) Reconsideration of the BacopaHerpestis problem of the Scrophulariaceae. Proceedings of the Academy of Natural Sciences of Philadelphia 98: 83-98.
Pott VJ \& Pott A (2000) Plantas aquáticas do Pantanal. Embrapa Comunicação para Transferência de Tecnologia, Distrito Federal. 404p.

Scatigna AV, Souza VC, Pereira CG, Sartori MA \& Simões AO (2015). Philcoxia rhizomatosa (Gratioleae, Plantaginaceae): a new carnivorous species from Minas Gerais, Brazil. Phytotaxa 226: 275-280.

Scatigna AV, Souza VC \& Simões AO (2017) Stemodia cipoensis (Plantaginaceae): a new species from Serra do Cipó, Minas Gerais, Brazil. Systematic Botany 42: 371-377.

Sculthorpe CD (1985) The biology of aquatic vascular plants. Koeltz Scientific Books, Königstein. 610p.

Souza VC \& Giulietti AM (2009) Levantamento das espécies de Scrophulariaceae sensu lato nativas do Brasil. Pesquisas, Botânica 60: 7-288.

Turner BL \& Cowan CC (1993a) Taxonomic overview of Stemodia (Scrophulariaceae) for North America and the West Indias. Phytologia 74: 61-103.

Turner BL \& Cowan CC (1993b) Taxonomic overview of Stemodia (Scrophulariaceae) for South America. Phytologia 74: 281-324.

Wettstein RV (1891) Scrophulariaceae. In: Engler A, Prantl K (eds.) Die natürlichen Pflanzenfamilien IV, 3: 39-107.

Velasquez J (1994) Plantas aquáticas vasculares da Venezuela. Universidad Central de Venezuela, Caracas. 992p.

\section{List of exsiccates}

Arruda AJ 882 (3.1), 1058 (1.3), 1196 (1.3). Cardoso A 2001 (2.1). Cavalcante P 2652 (2.1). Harley RM 57494 (1.3). Mota NFO 1164 (3.1), 2559 (1.1), 2573 (1.1), 2954 (1.3), 2972 (1.3), 2989 (1.3), 3407 (1.2), 3412 (1.1), 3432 (1.1). Pivari MO 1476 (1.3), 1487 (1.3), 1507 (1.1), 1508 (1.1), 1519 (1.3), 1574 (1.3). Secco R 191 (1.2). Silva ASL 1862 (2.1). Silva BRS 3 (1.3). Silva JP 432 (2.1). Silva LVC 1324 (1.1). Vasconcelos LV 827 (1.3). Viana PL 5687 (1.3). 
